Ekspansi: Jurnal Ekonomi, Keuangan, Perbankan dan Akuntansi

ISSN (Online): 2580-7668 ISSN (Print): 2085-5230

Vol. 11, No. 1 (Mei 2019), Hal. 23 - 34

\title{
PENGARUH KINERJA KEUANGAN TERHADAP PERUBAHAN HARGA SAHAM BANK UMUM SYARIAH NASIONAL DI BURSA EFEK INDONESIA (Studi Kasus: PT Bank Panin Dubai Syariah, Tbk.)
}

\author{
Benny Barnas ${ }^{1}$ \\ ${ }^{1}$ Jurusan Akuntansi, Politeknik Negeri Bandung, Bandung, Indonesia \\ Email Korespondensi: benny.barnas@polban.ac.id
}

\begin{abstract}
The purpose of this research is to examine the effect of Financial Performance, namely Return on Assets (ROA) and Earnings Per Share (EPS) on the stock price's changes of National Sharia Commercial Banks are listed on the Indonesia Stock Exchange (IDX). The research hypothesis was analyzed using multiple linear regression methods, while the financial data is taken from Bank Panin Dubai Syariah, Tbk. with the period of 2014-2017. The results indicate that Return on Assets (ROA) and Earnings per Share (EPS) both partially and simultaneously influence on stock prices. However, the result of adjusted $R^{2}$ show that 38,30 percent of stock prices are influenced by the Return on Assets (ROA) and Earning per Share (EPS), while 87,90 percent is influenced by other variables outside this model.
\end{abstract}

Keywords: Return on Asset (ROA), Earning per Share (EPS), and Price of Share.

Abstrak: Penelitian ini bertujuan untuk menguji pengaruh kinerja keuangan, yaitu return on asset (ROA) dan earning per share (EPS) terhadap perubahan harga saham Bank Umum Syariah Nasional di Bursa Efek Indonesia (BEI). Metode yang digunakan dalam penelitian ini adalah test hipotesis dengan menggunakan metode regresi linear berganda, dari data harga saham di Bursa Efek Indonesia dan laporan keuangan publikasi Bank Panin Dubai Syariah, Tbk. Hasil penelitian ini menunjukkan bahwa Return on Asset (ROA) dan Earning per Share (EPS) keduanya berpengaruh secara signifikan dan simultan terhadap harga saham. Sementara hasil pengujian seberapa besar pengaruh Return on Asset (ROA) dan Earning Per Share (EPS) dapat memengaruhi harga saham, maka dari hasil penelitian menunjukkan bahwa 38,30 persen harga saham dipengaruhi oleh variabel Return on Asset (ROA) dan Earning Per Share (EPS), sedangkan sisanya yaitu 87.90 persen banyak dipengaruhi oleh variabel-variabel lain di luar model ini.

Kata Kunci: Return on Asset (ROA), Earning per Share (EPS), dan Harga Saham

DOI: $10.35313 /$ ekspansi.v11i1.1327

Riwayat Artikel:

Diterima: $15-11-2018$

Direvisi: $25-2-2019$

Disetujui: $1-3-2019$ 


\section{PENDAHULUAN}

Karakteristik sistem perbankan syariah yang beroperasi berdasarkan prinsip bagi hasil, dan memberikan alternatif sistem perbankan yang saling menguntungkan baik bagi masyarakat maupun bank. Artinya menonjolkan aspek keadilan dalam bertransaksi, investasi yang beretika, mengedepankan nilai-nilai kebersamaan dan persaudaraan dalam berproduksi, dan menghindari kegiatan spekulatif, maka perbankan syariah menjadi alternatif bagi sistem perbankan yang kredibel dan dapat dinikmati oleh seluruh golongan masyarakat Indonesia tanpa terkecuali.

Perbankan syariah nasional lebih diarahkan pada pelayanan pasar domestik yang potensinya masih sangat besar, namun menurut laporan Bank Indonesia, market share bank umum Syariah dibandingkan dengan perbankan konvensional masih rendah, baik untuk total asset, pembiayaan, dan Dana Pihak Ketiga, rata-rata dari tahun 2014 sampai dengan 2017, masing-masing adalah 3,71 persen, 2,66 persen, dan 3,78 persen. Penyebab utamanya, bahwa industri perbankan Syariah baru diterapkan di Indonesia pada tahun 1991, dan sampai dengan akhir tahun 2017, tercatat 13 Bank Umum Syariah di Indonesia dengan 467 jaringan kantor cabang, dan 1.175 jaringan kantor cabang pembantu.

Berbagai macam cara perbankan Syariah untuk dapat bersaing baik ditingkat nasional maupun internasional, diantaranya dengan meningkatkan modal dan aset, menggandeng mitra strategis, dan melakukan penawaran saham ke publik atau Initial Public Offering/ IPO. Secara umum, nilai suatu perusahaan digambarkan dengan adanya perkembangan harga saham perusahaan tersebut di pasar modal (Rusli, A, dan Dasa, T, 2014). Semakin tinggi harga saham suatu perusahaan, maka semakin tinggi pula nilai perusahaan tersebut. Sementara harga saham di pasar modal dipengaruhi oleh beberapa faktor internal maupun eksternal, diantaranya prospek kinerja suatu perusahaan, dividen yang dibagikan, suku bunga, dan kebijakan perekonomian nasional, serta isu-isu internasional. Untuk mengukur kinerja suatu perusahaan, investor akan melihat kinerja keuangan perusahaan tersebut, seperti rasio-rasio Return on Asset (ROA), Return on Equity (ROE), Capital Adequacy Ratio (CAR), Non Performing Financing (NPF), Financing to Deposit Ratio (FDR), Beban Operasional dan Pendapatan Operasional (BOPO), dan Earning per Share (EPS), sebagai indikator pengukuran yang digunakan. Dengan harapan agar investasinya mampu memberikan tingkat pengembalian (rate of return), yaitu keuntungan yang relatif tinggi namun dengan risiko kerugian sekecil mungkin.

Saat ini, dari 13 jumlah Bank Umum Syariah (BUS), yang beroperasi di Indonesia, hanya ada satu perusahaan yang mencatatkan sahamnya di Bursa Efek Indonesia pada tanggal 15 Januari 2014, yaitu PT Bank Panin Dubai Syariah, Tbk. (dengan nama PNBS). Harga penawaran perdana saham PNBS adalah Rp.100, dan jumlah sahamnya sebanyak 4.75 miliar lembar. PT Bank Panin Dubai Syariah, Tbk. didirikan pada tanggal 8 Januari 1972, di Malang, dengan nama PT Bank Pasar Bersaudara Djaja. PT Bank Panin Dubai Syariah telah beberapa kali melakukan perubahan nama, sampai pada tanggal 19 April 2016 diubah sampai sekarang menjadi PT Bank Panin Dubai Syariah, Tbk. sehubungan dengan masuknya Dubai Islamic Bank PJSC sebagai salah 
satu Pemegang Saham Pengendali. Dengan komposisi pemegang saham, yaitu PT Bank Panin Indonesia, Tbk. sebesar 45 persen, Dubai Islamic Bank PSJC 38 persen, dan sisanya yaitu 17 persen dimiliki oleh masyarakat.

Sementara pada pergerakan saham PNBS triwulanan tahun 2014 cenderung mengalami kenaikan, rata-rata 12 persen, tahun 2015 rata-rata naik 6 persen, dan tahun 2016 rata-rata turun 22 persen, serta tahun 2017 rata-rata turun 20 persen. Penurunan ini terutama disebabkan karena menurunnya kinerja perusahaan, yang diakibatkan memburuknya kualitas pembiayaan. Dari sisi asset PNBS pada akhir tahun 2017, mencapai Rp8.63 Triliun, atau 3 persen dari market share industry bank umum Syariah Nasional. Sementara total pembiayaan dengan periode yang sama mencapai Rp6,54 Triliun, atau 3,45 persen dari market share industry bank umum Syariah Nasional, dan pencapaian penghimpunan dana pihak ketiga mencapai Rp7,53 Triliun, atau 3,16 persen dari market share industry bank umum Syariah nasional. Walaupun PNBS sudah melakukan beberapa cara untuk dapat bersaing baik ditingkat nasional maupun internasional, diantaranya dengan meningkatkan modal dan aset, yaitu menggandeng mitra strategis, dan melakukan penawaran saham ke publik atau Initial Public Offering/IPO, masih belum optimal meningkatkan kinerjanya, yang dibuktikan dengan rendahnya pencapaian market share di industry perbankan Syariah nasional, sebagai akibat kurangnya kepercayaan publik untuk berinvestasi satu-satunya saham perbankan Syariah di Indonesia.

Dari uraian di atas, peneliti tertarik untuk melakukan penelitian tentang "Pengaruh Kinerja Keuangan Terhadap Perubahan Harga Saham Bank Umum Syariah di Bursa Efek Indonesia”. Dalam hal ini studi kasusnya di PT Bank Panin Dubai Syariah, Tbk, dan rasio yang digunakan adalah Return on Asset (ROA) dan Earning Per Share (EPS).

\section{TINJAUAN PUSTAKA}

\subsection{Return on Asset (ROA)}

Return on Asset (ROA) merupakan perbandingan antara net income dengan total assets, rasio ini digunakan untuk mengukur efektivitas perusahaan dalam menghasilkan keuntungan dengan memanfaatkan seluruh sumber daya yang dimilikinya (Angela, A, 2014). Selanjutnya menurut Watung, R W, dan Ilat, V, yang mengacu pada konsep Kasmir, 2012, ROA merupakan suatu pengukuran kemampuan suatu perusahaan secara keseluruhan untuk menghasilkan keuntungan dengan jumlah keseluruhan aktiva yang tersedia pada perusahaan tersebut. Selain itu, menurut Rusli, A, dan Dasar T, 2014, ROA menggambarkan kemampuan asset-asset yang dimiliki suatu perusahaan dapat menghasilkan laba.

Dari uraian diatas dapat dikatakan bahwa, semakin besar ROA menunjukkan kinerja perusahaan semakin baik, karena return semakin besar, rumusnya adalah sebagai berikut, Angela, A, 2014:

$$
\text { Return on Assets }(\mathrm{ROA})=\frac{\text { Laba sebelum pajak }}{\text { Rata-rata total aset }}
$$




\subsection{Earning Per Share (EPS)}

Earning Per Share (EPS) atau pendapatan perlembar saham adalah bentuk pemberian keuntungan yang diberikan kepada para pemegang saham dari setiap lembar saham yang dimiliki (Egam, G. E. Y, Ilat V, dan Pangerapan S, 2017). Menurut Watung, R W, dan Ilat, V, 2016, yang mengacu pada konsep Pouraghajan, et al, 2013, Earning Per Share (EPS) merupakan indikasi laba dari masing-masing saham biasa, dan biasanya sering digunakan untuk menilai profitabilitas sekaligus risiko yang berhubungan dengan keuntungan dan penilaian tentang harga saham. Lebih lanjut menurut Agustina, L, dan Noviri S, 2013, yang mengacu pada konsep Susanna, 2000, EPS merupakan proxy untuk laba per saham perusahaan, yang diharapkan dapat memberikan gambaran bagi investor mengenai bagian keuntungan yang dapat diperoleh dalam suatu periode tertentu atas kepemilikan suatu saham. Selain itu, menurut Agustina, L, dan Noviri S, 2013, yang mengacu pada konsep Mohamad, 2006, apabila investor membeli saham, artinya mereka membeli prospek perusahaan, yang tercermin pada laba per saham. Jika laba per saham mengalami kenaikan, maka prospek perusahaan lebih baik, sementara jika laba per saham mengalami penurunan, bahkan negatif berarti tidak baik.

Dari uraian di atas dapat dikatakan bahwa, semakin tingggi EPS menunjukkan bahwa kinerja perusahaan semakin baik, yang artinya bisnis tersebut memberikan pengembalian hasil yang menguntungkan bagi pemilik modal, rumusnya adalah sebagai berikut, Agustina L \& Noviri S, 2013:

$$
\text { Earning per Share }(\text { EPS })=\frac{\text { Laba Bersih }}{\text { Jumlah Saham Beredar }}
$$

\subsection{Harga Saham}

Sebelum membahas tentang saham, maka terlebih dahulu akan dibahas tentang go public, yaitu apabila suatu perusahaan memutuskan untuk menjual saham kepada public, selain public memiliki saham juga dapat menilai kinerja perusahaan tersebut secara terbuka. Dengan semakin banyak perusahaan yang melakukan Initial Public Offering (IPO) atau biasa disebut go public, akan mengundang para investor untuk berinvestasi di pasar saham. Investor yang berinvestasi dipasar modal pada dasarnya bertujuan untuk memperoleh keuntungan yang sebesar-besarnya dengan risiko kerugian yang sekecil-kecilnya. Keputusan investor untuk berinvestasi dipasar saham dapat mempunyai peran penting dalam menentukan tren pasar, kemudian dapat mempengaruhi perekonomian nasional, Watung, R W, dan Ilat, V, 2016, yang mengacu pada konsep Kengatharan, 2014. Saham merupakan hak pemodal untuk memperoleh bagian dari kekayaan suatu perusahaan, dan merupakan instrument investasi yang banyak dipilih para investor karena saham mampu memberikan tingkat keuntungan yang menarik. Terdapat 2 jenis saham yang paling umum dikenal yaitu (Fahmi, 2012: 81), yaitu 1) saham biasa (suatu surat berharga yang dijual oleh suatu perusahaan yang mencantumkan nilai nominal, dan di akhir tahun apabila perusahaan itu memperoleh keuntungan, akan dibagikan dalam bentuk deviden), 2) saham 
istimewa, adalah suatu surat berharga yang dijual oleh suatu perusahaan yang mencantumkan nilai nominal, di mana pemegang sahamnya akan memperoleh pendapatan tetap dalam bentuk deviden yang akan diterima setiap triwulan (tiga bulanan).

Harga Saham merupakan harga suatu saham perusahaan, yang terjadi dipasar modal pada saat tertentu, dan ditentukan oleh pelaku pasar atas permintaan dan penawaran harga saham. Mehrani, H, dan Syafitri, L (2013), yang mengacu pada H.M Jogiyanto (2000). Harga pasar saham terbentuk melalui mekanisme permintaan (demand) dan penawaran (supply) di pasar modal, jadi apabila kinerja perusahaan mengalami perkembangan yang baik, maka harga saham cenderung akan meningkat. Menurut Gerald Edsel Yermia Egam, G.E.Y, Ilat, V, dan Pangerapan, S (2017), harga saham adalah harga perlembar saham yang berlaku di pasar modal. Di pasar modal pergerakan harga saham terdiri atas tiga kategori, yaitu harga tertinggi (high price), harga terendah (low price) dan harga penutupan (close price). Informasi mengenai laba per saham dapat dilihat selain dalam laporan rugi-laba perusahaan di Bursa Efek Indonesia maupun di website perusahaan dimaksud.

Faktor - faktor yang mempengaruhi perubahan harga saham yaitu faktor internal dan faktor eksternal. Faktor internal biasa disebut sebagai faktor fundamental adalah faktor yang berasal dari dalam perusahaan dan dapat dikendalikan oleh manajemen perusahaan sendiri, seperti factor yang berkaitan dengan pendapatan yang akan diperoleh para pemodal, yaitu baik berupa dividen maupun capital gain. Sementara faktor eksternal merupakan faktor non-fundamental, biasanya bersifat makro, seperti situasi politik dan keamanan, perubahan nilai tukar mata uang, naik turunnya suku bunga bank dan lain-lain.

\subsection{Kerangka Pemikiran}

\subsubsection{Pengaruh Return on Asset (ROA) Terhadap Harga Saham}

Pengukuran kinerja keuangan suatu perusahaan, salah satunya dapat di lihat dari rasio Return on Asset (ROA), yaitu suatu rasio yang menunjukkan kemampuan suatu perusahaan atas modal yang diinvestasikan dalam keseluruhan aktiva yang dimiliki untuk menghasilkan laba. ROA juga menunjukkan seberapa efisien suatu perusahaan dalam melakukan kegiatan usahanya.

Semakin tinggi ROA akan mengakibatkan semakin tingginya kemampuan suatu perusahaan untuk menghasilkan keuntungan. Atau dapat dikatakan bahwa, semakin tinggi keuntungan yang dihasilkan suatu perusahaan akan mengakibatkan semakin tingginya investor, yang tertarik akan nilai saham perusahaan tersebut, dengan mengakibatkan harga saham naik.

$\mathrm{H}_{1}$ : Return on Asset (ROA) berpengaruh positif terhadap Harga Saham

\subsubsection{Pengaruh Earning Per Share (EPS) terhadap Harga Saham}

Rasio Earning Per Share (EPS) atau laba per lembar saham merupakan hasil bagi antara laba bersih suatu perusahan dengan jumlah saham yang beredar. Rasio EPS menggambarkan jumlah rupiah yang diperoleh investor untuk setiap lembar saham 
yang dimilikinya. Investor akan tertarik pada suatu saham yang memberikan tingkat EPS yang tinggi, karena hal ini merupakan salah satu indikator keberhasilan perusahaan tersebut. Apabila laba per saham suatu perusahaan meningkat, maka mengakibatkan banyak investor tertarik untuk berinvestasi saham perusahaan tersebut. $\mathrm{H}_{2}$ : Earning Per Share (EPS) berpengaruh positif terhadap Harga Saham

\subsubsection{Pengaruh Return on Asset (ROA) dan Earning Per Share (EPS) terhadap Harga Saham}

Rasio Return on Asset (ROA) dan Earning Per Share (EPS) merupakan rasio pengukuran kinerja keuangan suatu perusahaan, yaitu apabila suatu perusahaan efisien dalam melakukan kegiatannya, maka perusahaan tersebut dapat menghasilkan keuntungan yang optimal. Keberhasilan kinerja suatu perusahaan ini dapat mengakibatkan harga saham naik, yang artinya investor akan mendapatkan jumlah uang yang besar untuk setiap lembar saham yang dimilikinya. Untuk mencapai keberhasilan ini, perusahaan akan berusaha menggunakan sumber dayanya secara optimal.

$\mathrm{H}_{3}$ : Return on Asset (ROA) dan Earning Per Share (EPS) berpengaruh positif terhadap Harga Saham

Dengan demikian, model penelitian dari uraian di atas adalah sebagai berikut:

Gambar 1. Model Penelitian ROA, EPS, dan Harga Saham

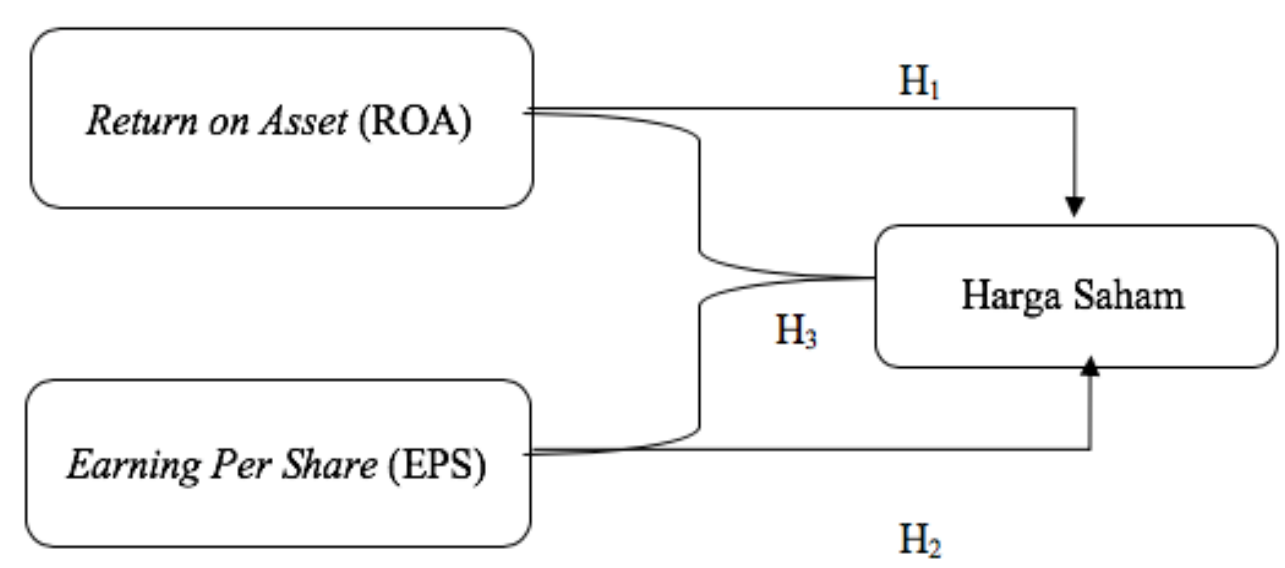

\section{METODE PENELITIAN}

Subjek penelitian ini adalah bank umum Syariah, yang telah mencatatkan sahamnya di Bursa Efek Indonesia, yaitu PT Bank Panin Dubai Syariah, Tbk. Data yang dikumpulkan dalam penelitian ini merupakan data sekunder, yaitu laporan keuangan publikasi triwulanan dan annual report Bank Umum Syariah yang terdaftar di BEI yaitu PT Bank Panin Dubai Syariah, Tbk., periode 2014 sampai dengan tahun 2017, dan data-data penunjang lainnya. 
Untuk menganalisis data dalam penelitian ini dilakukan uji asumsi klasik, yaitu uji normalitas, uji multikolinearitas, dan uji autokorelasi. Selanjutnya dilakukan uji regresi dan determinasi dengan variable independen $/ \mathrm{X}_{1}$ (ROA), $\mathrm{X}_{2}$ (EPS), dan variable dependen/Y (harga saham). Harga saham, yang digunakan adalah closing price saham Bank Panin Dubai Syariah, Tbk. (PNBS) di Bursa Efek Indonesia (BEI).

Alat yang digunakan untuk menguji hipotesis dalam penelitian ini adalah regresi linear berganda (multiple regression analysis) dengan menggunakan SPSS (Statistical Package for Social Science) System untuk menguji 2 (dua) variable independent, yaitu Return On Asset (ROA) dan Earning Per Share (EPS), yang diprediksi memengaruhi variable dependen, yaitu harga saham. Adapun model regresinya adalah sebagai berikut:

Dimana:

$$
Y=\alpha+\beta_{1} X_{1}+\beta_{2} X_{2}
$$

Y $=$ variabel dependen/harga saham

$\alpha \quad=$ Konstanta

$\beta_{1}$, dan $\beta_{2}=$ koefisien regresi

$\mathrm{X}_{1}$, dan $\mathrm{X}_{2}=$ variabel independent, $\mathrm{X}_{1}$ : Return on Asset $(\mathrm{ROA})$, dan $\mathrm{X}_{2}$ : Earning per Share (EPS)

\section{HASIL DAN PEMBAHASAN}

Hasil pengolahan data dengan menggunakan Aplikasi SPSS System, dapat di jelaskan sebagai berikut:

\subsection{Uji Asumsi Klasik}

\subsubsection{Uji normalitas,}

Tabel 1. Tests of Normality

\begin{tabular}{|l|r|r|r|r|r|r|}
\hline \multirow{2}{*}{} & \multicolumn{3}{|c|}{ Kolmogorov-Smirnov $^{\text {a }}$} & \multicolumn{3}{c|}{ Shapiro-Wilk } \\
\cline { 2 - 7 } & Statistic & \multicolumn{1}{c|}{ df } & \multicolumn{1}{c|}{ Sig. } & \multicolumn{1}{c|}{ Statistic } & \multicolumn{1}{c|}{ df } & \multicolumn{1}{l|}{ Sig. } \\
\hline ROA &, 231 & 13 &, 056 &, 889 & 13 &, 094 \\
\hline EPS &, 195 & 13 &, 187 &, 909 & 13 &, 180 \\
\hline HSAHAM &, 102 & 13 &, $200^{*}$ &, 963 & 13 &, 801 \\
\hline
\end{tabular}

*. This is a lower bound of the true significance.

a. Lilliefors Significance Correction

Berdasarkan hasil test uji normalitas menggunakan uji explorer dengan metode Kolmogorov-Smirnov dan Shapiro-Wilk menunjukkan bahwa nilai Uji signifikan untuk varaibel EPS dan Harga Saham, masing-masing sebesar 0,187 dan 0,200 atau > $0,10(\alpha=10 \%)$, dan varaibel ROA sebesar 0,056 atau $<01,0((\alpha=10 \%)$, dengan demikian data secara univariat dinyatakan terdistribusi normal, kecuali ROA.

\subsubsection{Uji Multikolinearitas,}

Hasilnya adalah variabel ROA dan variabel EPS sama-sama memiliki tolerance 0,727 atau di atas 0,1, dan VIF masing-masing sebesar 1,055 atau di bawah 10, maka 
dapat dikatakan bahwa variabel independent, yaitu ROA dan EPS terbebas dari multikolinearitas.

\subsubsection{Uji Autokorelasi}

Hasil uji Autokorelasi menunjukkan Asymp sig sebesar 0,067 atau > alpha $(\alpha) 0,10$; yang artinya bahwa tidak terjadi autokorelasi.

\subsection{Hasil Pengujian}

4.2.1 Pengujian Model Regresi

Tabel 2. ANOVA ${ }^{\mathrm{a}}$

\begin{tabular}{|l|l|l|l|l|l|l|}
\hline \multicolumn{2}{|l|}{ Model } & Sum of Squares & df & Mean Square & F & Sig. \\
\hline \multirow{4}{*}{1} & Regression & 16734,082 & 2 & 8367,041 & 3,369 &, $046^{\mathrm{b}}$ \\
\cline { 2 - 8 } & Residual & 24837,149 & 10 & 2483,715 & & \\
\cline { 2 - 7 } & Total & 41571,231 & 12 & & & \\
\hline
\end{tabular}

a. Dependent Variable: HSAHAM

b. Predictors: (Constant), EPS, ROA

Berdasarkan Tabel Anova di atas, menunjukkan bahwa hasil uji $F_{\text {hitung }}$ adalah sebesar 3,369, dan $F_{\text {tabel }} 2,281$, jadi $F_{\text {hitung }}>F_{\text {tabel}}$, atau model ditolak. Sementara nilai Sig sebesar 0,046 atau < alpha $(\alpha) 0,10$. Dengan demikian dapat disimpulkan bahwa Return on Asset (ROA) dan Earning Per Share (EPS) berpengaruh signifikan terhadap perubahan harga saham secara simultan.

\subsubsection{Pengujian Hipotesis}

Tabel 3. Coefficients ${ }^{\mathrm{a}}$

\begin{tabular}{|c|c|c|c|c|c|c|}
\hline \multirow{2}{*}{\multicolumn{2}{|c|}{ Model }} & \multicolumn{2}{|c|}{$\begin{array}{c}\text { Unstandardized } \\
\text { Coefficients }\end{array}$} & \multirow{2}{*}{$\begin{array}{l}\text { Standardized } \\
\text { Coefficients } \\
\text { Beta }\end{array}$} & \multirow[b]{2}{*}{$t$} & \multirow[b]{2}{*}{ Sig. } \\
\hline & & $\mathrm{B}$ & Std. Error & & & \\
\hline 1 & (Constant) & 191,266 & 29,221 & & 6,545 &, 000 \\
\hline & ROA & $-2,346$ & 25,342 &,- 026 &,- 093 & ,928 \\
\hline & EPS & 1,347 & ,594 & ,648 & 2,269 & ,047 \\
\hline
\end{tabular}

a. Dependent Variable: HSAHAM

Hasil pengujian hipotesis secara parsial pada Tabel Coefficient di atas, dapat di interpretasikan sebagai berikut:

a. Variabel Return on Asset (ROA) adalah 0,928 atau < alpha $(\alpha) 0,10$; maka dapat di interpretasikan bahwa $\mathrm{H}_{0}$ ditolak. Dengan demikian dapat disimpulkan bahwa Return on Asset berpengaruh terhadap Harga Saham.

b. Variabel Earning per Share (EPS) adalah 0,047 atau < alpha $(\alpha) 0,10$, maka dapat di interpretasikan bahwa $\mathrm{H}_{0}$ ditolak. Dengan demikian dapat disimpulkan bahwa Earning per Share (EPS) berpengaruh secara signifikan terhadap Harga Saham. 


\subsubsection{Hasil Persamaan Regresi Berganda}

Hasil pengolahan data responden pada Tabel Cefficients di atas, menunjukkan bahwa nilai constant $(\alpha)$ sebesar 191,266; dan variabel independen dengan $\beta$ masingmasing, yaitu $\beta_{1}$ (Return on Asset) sebesar -2,346; serta $\beta_{2}$ (Earning per Share) sebesar 1,347. Maka hasil uji regresi secara parsial dapat disimpulkan sebagai berikut:

$$
Y=\alpha+\beta_{1} X_{1}+\beta_{2} X_{2} \rightarrow Y=191,266-2,346 X_{1}+1,347 X_{2}
$$

Penjelasan persamaan regresi di atas adalah sebagai berikut:

$\alpha=+191,266$; artinya jika $\mathrm{X}_{1}$ (Return on Asset) dan $\mathrm{X}_{2}$ (Earning per Share) sebesar 0 atau tidak ada perubahan, maka Y (Harga Saham) meningkat sebesar Rp191,266.

$\beta_{1}=-2,346$; artinya jika $\mathrm{X}_{1}$ (Return on Asset) meningkat satu satuan, maka Y (Harga Saham) akan turun sebesar Rp2,346, jadi menunjukkan pengaruh yang diberikan oleh vafiabel ROA adalah negatif.

$\beta_{2}=+1,347$; artinya jika $X_{2}$ (Earning per Share) meningkat satu satuan, maka Y (Harga Saham) akan naik sebesar Rp1,347, jadi menunjukkan pengaruh yang diberikan oleh vafiabel ROA adalah positif.

\subsubsection{Uji Determinasi $\left(R^{2}\right)$}

Hasil pengolahan data responden untuk uji determinasi $(R)$, adalah sebagai berikut:

\begin{tabular}{|c|c|c|c|c|}
\hline \multicolumn{5}{|c|}{ Tabel 4. Model Summary ${ }^{b}$} \\
\hline Model & $\mathrm{R}$ & R Square & Adjusted R Square & $\begin{array}{l}\text { Std. Error of the } \\
\text { Estimate }\end{array}$ \\
\hline 1 &, $634^{\mathrm{a}}$ & ,403 & ,383 & 49,83688 \\
\hline
\end{tabular}

a. Predictors: (Constant), EPS, ROA

b. Dependent Variable: HSAHAM

Tabel Model Summary di atas, menunjukkan bahwa hasil uji determinasi, Adjusted $R^{2}$ sebesar 0,383 atau artinya perubahan harga saham dipengaruhi 38,30 persen oleh Return on Asset (ROA) dan Earning per Share (EPS), sedangkan sisanya yaitu 61,70 persen dijelaskan oleh sebab-sebab lain di luar model penelitian ini.

\subsection{PEMBAHASAN}

\subsubsection{Pengaruh ROA terhadap Harga Saham}

Hasil penelitian ini menunjukkan bahwa Return on Asset (ROA) berpengaruh terhadap perubahan harga saham, artinya apabila terjadi peningkatan maupun penurunan rasio ROA akan memengaruhi perubahan harga saham secara signifikan. Hasil penelitian ini konsisten dengan penelitian terdahulu, yang dilakukan oleh Mehrani H \& Syafitri L (2013), Rusli A \& Dasar T (2014, Ali M \& dkk (2017), Manoppo C P (2015), Widiawati R \& Ilat W (2016), Purnamasari Dyah (2015), Agustina L \& Noviri S (2013). 


\subsubsection{Pengaruh EPS terhadap Harga Saham}

Hasil penelitian ini menunjukkan bahwa Earning per Share (EPS) berpengaruh secara signifikan terhadap perubahan harga saham, artinya apabila terjadi peningkatan maupun penurunan rasio EPS akan memengaruhi perubahan harga saham secara signifikan. Hasil penelitian ini konsisten dengan penelitian terdahulu, yang dilakukan oleh Mehrani H \& Syafitri L (2013), Ali M \& dkk (2017), Manoppo C P (2015), Edsel G \& dkk (2017), Widiawati R \& Ilat W (2016), Purnamasari Dyah (2015), Agustina L \& Noviri S (2013).

\subsubsection{Pengaruh ROA dan EPS terhadap Harga Saham}

Hasil penelitian ini menunjukkan bahwa Return on Asset (ROA) dan Earning per Share (EPS) berpengaruh secara signifikan terhadap perubahan harga saham, artinya apabila terjadi peningkatan maupun penurunan rasio ROA dan EPS akan memengaruhi perubahan harga saham secara signifikan. Hasil penelitian ini konsisten dengan penelitian terdahulu, yang dilakukan oleh Mehrani H \& Syafitri L (2013), Idawati W \& Wahyudi A (2015), Manoppo C P (2015), Widiawati R \& Ilat W (2016), Purnamasari Dyah (2015), Agustina L \& Noviri S (2013).

\section{PENUTUP}

Hasil penelitian menunjukan Return on Asset (ROA) dan Earning Per Share (EPS) dapat memengaruhi harga saham, dengan hasil penelitian menunjukkan bahwa 38,30 persen harga saham dipengaruhi oleh variabel Return on Asset (ROA) dan Earning Per Share (EPS), sedangkan sisanya yaitu 87,90 persen banyak dipengaruhi oleh variabelvariabel lain di luar model ini. Hasil pengujian secara parsial dan simultan menunjukkan bahwa Return on Asset (ROA) dan Earning Per Share (EPS) keduanya berpengaruh terhadap perubahan harga saham.

Diharapkan perusahaan lebih meningkatkan kinerjanya secara terukur melalui Earning per Share (EPS) untuk menarik minat investor berinvestasi saham. Karena ROA merupakan pedoman perhitungan rasio keuangan yang dikeluarkan oleh OJK (POJK No.8/POJK.03/2014 tentang penilaian Tingkat Kesehatan Bank Umum Syariah dan Unit Usaha Syariah), yaitu rasio rentabilitas bank. Semakin baik tingkat kesehatan Bank, maka akan baik pula performa saham perusahaan tersebut, baik ditingkat nasional maupun internasional melalui perdagangan saham di pasar modal. Hal ini dapat mendorong bank umum Syariah lainnya untuk segera mencatatkan sahamnya di bursa efek Indonesia, agar dapat mengikuti persaingan global.

\section{DAFTAR PUSTAKA}

Agustina, L., dan Noviri, S., 2013, "Pengaruh Return on Asset (ROA), Earning Per Share (EPS), dan Tingkat Suku Bunga SBI Terhadap Harga Saham (Studi Pada Indeks LQ45 Tahun 2010"), Jurnal Akuntansi Vol.5 No.1 Mei 2013: 1-23; 
Angela, A., (2014), "Pengaruh Implementasi Total Quality Management Terhadap Kinerja Bank Umum dengan Budaya Organisasi dan Sistem Penghargaan sebagai Variabel Moderasi”, Jurnal Akuntansi Vol.6 No.2 November 2014: 42 - 58;

Ali, M., A., Kalim, U., Raza, H., Ali, H., A., and Rehman, M., 2017, "The Relationship Between ROA, ROE, ROCE and EPS Ratios with Break-up Values of Shares of KarachiPakistan Fuel and Energy Listed Companies", Journal of Finance and Accounting 2017; 5(3): 115-122;

Egam, G., E., Y., Ilat, V., and Pangerapan, S., 2017, "Pengaruh Return On Asset (ROA), Return On Equity (ROE), Net Profit Margin (NPM), Dan Earning Per Share (EPS) Terhadap Harga Saham Perusahaan Yang Tergabung Dalam Indeks LQ45 Di Bursa Efek Indonesia Periode Tahun 2013-2015”, Jurnal EMBA Vol.5 No.1 Maret 2017, Hal. 105 - 114;

Idawati, W., dan Wahyudi, A., 2015, "Effect of Earning Per Shares (EPS) and Return On Assets (ROA) against Share Price on Coal Mining Company Listed in Indonesia Stock Exchange", Journal of Resources Development and Management ISSN 2422-8397 An International Peer-reviewed Journal Vol.7, 2015;

Manoppo, C., A., 2015, “The Influence Of Roa, Roe, Ros, And Eps On Stock Price”, Jurnal EMBA 691, Vol.3 No.4 Desember 2015, Hal. 691-697;

Mehrani, H., dan Syafitri, L., Pengaruh Return On Investment (OIi), Earning Per Share (EPS), Dan Price Earning Ratio (PER) Terhadap Harga Saham Pada Pt. Indofood Sukses Makmur Tbk, 2013;

Purnamasari, D., 2015, The Effect of Changes in Return on Assets, Return on Equity, and Economic Value Added to the Stock Price Changes and Its Impact on Earnings Per Share", Research Journal of Finance and Accounting ISSN 2222-1697 (Paper) ISSN 2222-2847, Vol.6, No.6, 2015,

Rusli, A., dan Dasar T., 2014, "Pengaruh Rasio Keuangan Terhadap Harga Saham Pada Perusahaan Bumn Perbankan Yang Terdaftar Di Bursa Efek Indonesia”, Jurnal Akuntansi, Vol. 01, No.02, Juli 2014;

Ulzanah, A., A., and Murtaqi, I., 2015, “The Impact of Earnings Per Share, Debt To Equity Ratio, And Current Ratio Towards The Profitability Of Companies Listed In Lq45 From 2009 To 2013", Journal Of Business And Management Vol. 4, No.1, 2015: 18 27 ;

Watung, R., W., dan Ilat, V., 2016, "Pengaruh Return On Asset (ROA), Net Profit Margin (NPM), Dan Earning Per Share (EPS) Terhadap Harga Saham Pada Perusahaan Perbankan Di Bursa Efek Indonesia Periode 2011-201"5, Jurnal EMBA Vol.4 No.2 Juni 2016, Hal. 518-529;

Sunjoyo, dkk, 2013, Aplikasi SPSS untuk SMART Riset;

https://www.bi.go.id/, Sekilas Perbankan Syariah Di Indonesia;

https://www.bi.go.id/id/publikasi/ekonomi-keuangan-kerjasama-internasional/ https://islamicmarkets.com/publications/pt-bank-panin-dubai-syariah-tbk-annualreport-2016

http://www.idx.co.id/StaticData/NewsAndAnnouncement/announcementstock/ https://www.ojk.go.id/ 
https://www.paninbanksyariah.co.id/index.php/mtentangkami/laporankeuangan 